\title{
CAMPUR KODE PADA KOMUNIKASI LISAN ANTAR PARA PELAKU PERCAKAPAN DI PASAR GROSIR SETONO PEKALONGAN
}

\author{
Ida Ayu Panuntun \\ Fakultas Keguruan dan Ilmu Pendidikan, Universitas Pekalongan \\ Email: ayyu_idda@yahoo.com
}

\begin{abstract}
Communication is a media in transferring idea between speaker and hearer. Oral communication often used by the speaker and hearer in achieving the aim of communication. Most of Indonesian people, included Pekalongan people are bilingual. They use Javanese language as their daily language. However, as Indonesian people, they also master and use Indonesian language in their conversation. Sometimes, they often mix Javanese and Indonesian in their conversation. It also happened in the conversation between seller and buyer in Pasar Grosir Setono Pekalongan. Most of the sellers came from Pekalongan. It means that in providing services for the buyer, sometimes the sellers combined Indonesian and Javanese language. They often inserted another language in their conversation. The aim of this research was to describe the form of code mixing used between seller and buyer in Pasar Grosir Setono Pekalongan. The research design used in this research was descriptive qualitative. The instrument was observation sheet. There are 15 sellers and 17 buyers used as the sample in this research. The technique of analyzing data used in this research were identification, classification and interpretation. The finding of this research shows the form of code mixing used by the sellers and buyers in Pasar Grosir Setono Pekalongan were from Javanese to Indonesian and Indonesian to Javanese. From those code mixing, there were the type of intra-sentential and intra-lexical used in their utterances. Based on the existing result, it is necessary to have language training in the field of marketing. It is used to improve the seller's competence in speaking using Indonesian language and improve their confident to speak using Indonesian language.
\end{abstract}

Keywords: Code mixing, conversation, bilingual

\section{PENDAHULUAN}

Kedudukan manusia dalam kehidupan bermasyarakat tidak terlepas dari sebuah interaksi. Interaksi tersebut dilakukan antarindividu guna memenuhi kebutuhan satu sama lain. Oleh karena itu, manusia dikenal sebagai makhluk hidup yang tidak dapat berdiri sendiri.

Tidak dapat berdiri sendiri merupakan salah satu ciri nyata bahwa manusia merupakan makhluk sosial. Dalam mempertahankan kelangsungan hidupnya mereka harus saling membantu antarsesama. Adanya kerja sama antarindividu tersebut merupakan salah satu cara yang ditempuh dalam mempertahankan hidup mereka. Melalui sebuah komunikasi, interaksi individu dapat terlaksana dengan baik. Berdasarkan pernyataan Effendy (2002), komunikasi merupakan suatu wadah yang dimanfaatkan individu dalam proses memenuhi kebutuhan hidup masing-masing.

Interaksi antarindividu dapat terjalin dengan baik dengan adanya sebuah media perantara di dalamnya. Media yang dimaksud adalah bahasa.

Bahasa merupakan suatu media atau alat yang digunakan untuk menyampaikan ide, pikiran, pendapat antarindividu dalam mencapai tujuan komunikasi. Menurut Kridalaksana dan Kentjono (Chaer, 1994), bahasa merupakan lambang bunyi sewenang-wenang yang digunakan dalam melakukan kerja sama, komunikasi dan identifikasi diri pada suatu kelompok masyarakat.

Keberanekaragaman bahasa atau yang dikenal dengan sebutan multilingual di negara 
Indonesia ini, ternyata memunculkan berbagai fenomena bahasa, termasuk di Kota Pekalongan dalam lingkup yang lebih sempit. Sebagai contoh, sebagian besar masyarakat Kota Pekalongan merupakan masyarakat dwibahasa. Masyarakat Kota Pekalongan minimal menguasai lebih dari satu bahasa, yaitu Bahasa Jawa dan Bahasa Indonesia. Beberapa contoh fenomena bahasa yang dimaksud adalah penerapan prinsip kesantunan, prinsip kerja sama, munculnya tingkah laku berbahasa dan alih kode maupun campur kode dalam penggunaan bahasa. Fenomena tersebut muncul dan telah menjadi hal yang biasa di kalangan masyarakat.

Pada artikel ini, penulis menggali lebih dalam mengenai fenomena bahasa yang dikenal dengan campur kode pada percakapan antara para pelaku komunikasi di Pasar Grosir Setono Pekalongan.

Pasar Grosir Setono Pekalongan merupakan tempat bertemu dan sebagai tempat terjadinya interaksi antar penjual dan pembeli. Latar belakang para penjual dan pembeli juga bukan berasal dari satu lokasi yang sama. Oleh karena itu, akan banyak terjadi interaksi antara penjual dan pembeli dengan latar belakang yang berbeda-beda sehingga memungkinkan terjadinya bilingualisme atau yang lebih dikenal dengan istilah penggunaan lebih dari satu bahasa.

Sebagian besar penjual berasal dari Kota Pekalongan. Namun, berbicara tentang pembeli tentunya bukan berasal dari tempat yang sama. Mereka berasal dari kota yang berbeda-beda, sehingga komunikasi antar para penjual dan pembeli harus menggunakan lebih dari satu bahasa. Berdasarkan dari hasil pengamatan, penggunaan lebih dari satu bahasa antar penjual dan pembeli berfungsi untuk memperjelas maksud ujaran masing-masing penjual dan pembeli.

Berdasarkan latar belakang di atas, maka tujuan penelitian ini adalah untuk mendeskripsikan tipe campur kode yang digunakan antar penjual dan pembeli di Pasar Grosir Setono Pekalongan.

\section{TINJAUAN PUSTAKA}

Campur kode merupakan salah satu fenomena pertukaran bahasa. Pertukaran bahasa yang dimaksud adalah bahasa asing ke Bahasa Indonesia atau sebaliknya, Bahasa Indonesia ke bahasa daerah atau sebaliknya, dan memungkinkan juga antar bahasa daerah itu sendiri. Dalam percakapan antar pelaku komunikasi di Pasar Grosir Setono Pekalongan sering sekali para pelaku percakapan baik penjual maupun pembeli menyisipkan penggunaan bahasa lain. Sebagai contoh mereka sering menyelipkan satu atau lebih kata maupun frasa bahasa lain dalam percakapan mereka.

Menurut Kridalaksana (2001), definisi campur kode adalah penggunaan bahasa dari satu bahasa ke bahasa lain. Tujuan dari campur kode tersebut adalah untuk memperluas gaya bahasa. Penguasaan lebih dari satu bahasa menjadikan para pelaku percakapan terkadang menyelipkan bahasa lain yang mereka kuasai untuk membantu mengutarakan maksud atau tujuan percakapan.

Campur kode merupakan salah satu kajian dalam pembelajaran Sosiolinguistik. Menurut pernyataan Sumarsono (2011), pembelajaran sosiolinguistik menekankan pada kajian masyarakat dan kajian bahasa itu sendiri. Dengan kata lain, bahwa pembelajaran sosiolinguistik tersebut merupakan pembelajaran bahasa dalam kaitannya dengan hubungan kemasyarakatan. Berdasarkan pernyataan Sumarsono (2011), dapat disimpulkan bahwa makna bahasa dipengaruhi oleh konteks kemasyarakatan. Berdasarkan pernyataan Chaer, Abdul dan Agustina (2010), fungsi dari suatu bahasa adalah sebagai alat berinteraksi, yaitu dalam hal komunikasi. Komunikasi yang dimaksud adalah sebagai alat untuk menyampaikan pikiran, gagasan, konsep atau pun juga perasaan.

Proses terjadinya campur kode pada suatu percakapan, tidak semata-mata terjadi begitu saja. Hal ini terjadi dikarenakan adanya latar belakang dari para pelaku percakapan.

Berdasarkan pernyataan Hoffman (1991), campur kode dibedakan dalam tiga tipe. Ketiga tipe yang dimaksud adalah intra-sentential, intra-lexical dan a change of pronunciation. Masing-masing tipe campur kode tersebut memiliki ciri yang berbeda-beda. Adapun 
penjelasan masing-masing tipe campur kode di atas adalah sebagai berikut:

\section{a) Tipe intra-sentential}

Pada jenis tipe ini, maka campur kode pada sebuah percakapan muncul dalam bentuk frasa dan kalimat. Adapun contoh percakapan yang menyisipkan campur kode tipe intra-sentential adalah sebagai berikut:

Percakapan antara penjual dan pembeli:

$$
\begin{array}{ll}
\text { Penjual } & \text { Pados nopo mba? } \\
\text { Pembeli } & \begin{array}{l}
\text { : Lihat-lihat aja bu. Sae-sae } \\
\text { nggih bu }
\end{array} \\
\text { Penjual } & \text { : Lha monggo, dipirsani riyin. }
\end{array}
$$

Berdasarkan penggalan percakapan antara penjual dan pembeli di atas, maka tampak adanya campur kode pada salah satu ujaran, yaitu "Lihat-lihat aja bu." Pada kalimat "Lihat-lihat aja bu", salah satu penutur (pembeli) telah menyisipkan ujaran dalam Bahasa Indonesia dalam konteks percakapan Bahasa Jawa.

b) Tipe intra-lexical

Tipe berikutnya adalah campur kode tipe intra-lexical. Salah satu ciri yang tampak pada tipe jenis ini adalah campur kode muncul pada ikatan kata. Contoh percakapan yang mengandung campur kode tipe intra-lexical adalah sebagai berikut:

$\begin{array}{ll}\text { Penjual } & \text { : Bagus-bagus, kainnya bu } \\ \text { Pembeli } & \text { : Berapaan bu? } \\ \text { Penjual : Yang mana? } \\ \text { Pembeli } \quad \text { Dua meter, delapan puluh } \\ & \text { ribu, kainne bagus banget }\end{array}$

Berdasarkan percakapan di atas, maka tampak kata yang berupa ikatan kata, yaitu gabungan antara Bahasa Indonesia dan Bahasa Jawa, pada kata "kainne." Kata "kainne", berasal dari Bahasa Indonesia "kain" dan " $n e$ " dari Bahasa Jawa.

c) Tipe a change of pronunciation

Tipe a change of pronunciation menunjukkan ciri berupa adanya perubahan suara yang dikenal dengan phonological. Pada tipe ini, akan muncul perubahan bunyi dari bahasa sesungguhnya. Sebagai contoh pada kata "hello", diucapkan dalam Bahasa Indonesia "halo."
Tipe campur kode di atas adalah sebuah teori yang digunakan sebagai dasar untuk menganalisis ujaran dalam sebuah percakapan yang terjadi antara penjual dan pembeli di Pasar Grosir Setono Pekalongan.

\section{METODE PENELITIAN}

Pada penelitian ini, peneliti menggunakan desain penelitian berupa deskriptif kualitatif. Menurut pernyataan (Rahmadani, Putri Markinda, 2015), metode penelitian deskriptif kualitatif merupakan suatu metode yang menggambarkan dan mengintepretasikan suatu objek sesuai keadaan yang sebenarnya di lapangan. Sejalan dengan pernyataan di atas, (Moleong, 2010) pendekatan kualitatif merupakan suatu pendekatan dalam penelitian untuk memahami fenomena yang muncul tentang apa yang sedang dialami oleh subjek penelitian. Fenomena tersebut dapat berupa perilaku, persepsi, motivasi, tindakan atau yang lainnya. Berdasarkan pernyataan di atas, maka dapat disimpulkan bahwa pendekatan kualitatif merupakan suatu pendekatan yang mendeskripsikan fenomena yang muncul pada subjek.

Subyek pada penelitian ini adalah penjual dan pembeli di Pasar Grosir Setono Pekalongan. Jumlah penjual sebagai subyek penelitian ini adalah 15 orang, sedangkan pembeli yang digunakan sebagai subyek penelitian berjumlah 17 orang. Adapun lokasi penelitian ini adalah Pasar Grosir Setono Pekalongan.

Teknik pengambilan data pada penelitian ini adalah dengan melakukan observasi langsung ke lapangan. Instrumen dalam pengambilan data yang digunakan dalam penelitian ini berupa lembar observasi. Adapun data pada penelitian berupa transkip dari hasil observasi ketika di lapangan.

Prosedur selanjutnya adalah teknik dalam analisis data. Teknik analisis pada penelitian ini adalah identifikasi, klasifikasi dan interpretasi. Deskripsi masing-masing tahap pada teknik analisis data adalah sebagai berikut: (1) tahap identifikasi, pada tahap ini, peneliti mengidentifikasikan seluruh ujaran pada transkip percakapan antar penjual dan pembeli yang termasuk dalam ujaran yang mengandung 
campur kode; (2) tahap berikutnya adalah klasifikasi. Pada tahapan ini, maka peneliti mengklasifikasikan ujaran yang termasuk ke dalam masing-masing tipe campur kodenya; dan (3) terakhir, peneliti mengintepretasikan setiap tipe berdasarkan teori yang melandasi.

\section{HASIL DAN PEMBAHASAN}

Hasil penelitian berdasarkan analisis data di lapangan, maka ditemukan bahwa penggunaan campur kode pada ujaran dalam percakapan antar penjual dan pembeli di Pasar Grosir Setono Pekalongan terjadi dalam dua bentuk, yaitu Bahasa Indonesia ke Bahasa Jawa dan Bahasa Jawa ke Bahasa Indonesia. Penggunaan campur kode tersebut dikarenakan latar belakang daerah asal penjual Sebagian besar dari Kota Pekalongan dan pembeli dari kota-kota yang berbeda.

Berdasarkan ujaran yang muncul pada masing percakapan dengan subyek 15 orang penjual dan 17 pembeli, berikut beberapa contoh analisis data wujud campur kode antara penjual dan pembeli dalam bentuk frasa atau kalimat:

\section{Data 1 (Subyek 1)}

Pembeli 1 : sidone opo iki?

Pembeli 2 : klambi jare, jare arep njaluk lengen pendek

Penjual : pados nopo mba?

Pembeli 1 : pados baju batik

Penjual : monggo monggo, bagus bagus

Data 1 di atas menampilkan percakapan yang terdiri dari tiga pelaku percakapan, yaitu satu penjual dan dua pembeli. Percakapan tersebut terjadi di Pasar Grosir Setono Pekalongan. Para pelaku percakapan pada data 1 menggunakan Bahasa Jawa dalam menyampaikan maksud dan tujuan mereka. Akan tetapi, ada beberapa ujaran dari pelaku percakapan yang menyisipkan Bahasa Indonesia, yaitu pembeli 1 dan penjual. Pembeli 1 menyampaikan ujaran berupa "pados baju batik", "baju batik" merupakan ujaran yang telah menyisipkan Bahasa Indonesia, yaitu pada kata "baju." Berdasarkan konteks percakapan di atas, maka seharusnya pembeli 1 menggunakan bahasa yang sama pada frasa "baju batik" menjadi "klambi batik" Selain itu, campur kode juga ditemukan pada "bagus bagus", "bagus bagus" merupakan rangkaian kata-kata dengan menggunakan Bahasa Indonesia.

Berdasarkan analisis data di atas, maka dapat disimpulkan bahwa ujaran pada percakapan di atas mengandung campur kode tipe intra-sentential, yaitu pada kata "baju" dan "bagus".

Pada data berikutnya juga akan tampak percakapan yang mengandung campur kode berbentuk frasa atau gabungan kata. Percakapan tersebut muncul pada Data 2.

\begin{tabular}{|c|c|}
\hline \multicolumn{2}{|c|}{ Data 2 (Subyek 5) } \\
\hline Penjual & $\begin{array}{l}\text { : setelane mba, monggo mbc } \\
\text { cantik }\end{array}$ \\
\hline $\mathrm{mb}$ & : mboten bu \\
\hline & $\begin{array}{l}\text { mbok dipirsani riyin, sae-sa } \\
\text { lho, wernane tesih lengkap }\end{array}$ \\
\hline $\mathrm{emb}$ & : mpun gadhah bu \\
\hline inju & : niki terbaru $m b a$ \\
\hline hbeli & : nggih pun, cobi bu \\
\hline & $\begin{array}{l}\text { : mlebet mawon. Niki mba, } \\
\text { wernane jan apik-apik. Sing } \\
\text { terbaru kerah } \text { ngeten }\end{array}$ \\
\hline emb & : wonten sing merah bu? \\
\hline & : niki \\
\hline Pembeli & : walah gedhene. Sing alit bu \\
\hline Penjual & $\begin{array}{l}\text { : jal kulo padhoske. Wadul } \\
\text { kosong }\end{array}$ \\
\hline Pembeli & $\begin{array}{l}\text { nggih pun bu, mboten nope } \\
\text { nopo }\end{array}$ \\
\hline & : sanese mba \\
\hline & : mboten bu, kepengene niku \\
\hline
\end{tabular}

Tipe campur kode intra-sentential muncul pada ujaran "... mba cantik", "... tesih lengkap”, "niki terbaru...”, “...sing terbaru”, "...sing merah", "...waduh kosong”. Pada penggalan masing-masing ujaran tersebut menggunakan Bahasa Jawa sebagai alat komunikasi utama. Akan tetapi, muncul beberapa kata yang menggunakan Bahasa Indonesia.

Analisis pada ujaran "... mba cantik" menunjukkan bahwa kata cantik seharusnya menggunakan Bahasa Jawa, yaitu "ayu". Apabila menggunakan kata "ayu" maka tidak terjadi campur kode pada percakapan tersebut. Akan tetapi pada data ini, penjual menggunakan Bahasa Indonesia sehingga peristiwa campur 
kode terjadi di sini. Selain itu masih dengan konteks yang sama campur kode intrasentential tampak pada "... tesih lengkap". "Lengkap" merupakan kata dalam Bahasa Indonesia. Seharusnya menggunakan kata "pepek". Campur kode berikutnya yaitu "niki terbaru....", "Niki terbaru..." seharusnya "niki enggal...", "...sing terbaru”, seharusnya "... sing anyar". Yang terakhir adalah "...sing merah", seharusnya "...sing abrit" dan "...waduh kosong” seharusnya diganti dengan “... waduh telas".

Berdasarkan data di atas, dapat diketahui bahwa beberapa ujaran pada percakapan antara penjual dan pembeli telah menggunakan campur kode tipe intra-sentential.

Selain tipe campur kode intra-sentential, penggalan percakapan antara penjual dan pembeli di Pasar Grosir Setono Pekalongan terdapat beberapa ujaran yang mengandung campur kode tipe intra-lexical. Jenis campur kode tipe intra-lexical ini muncul berupa gabungan penggunaan satu bahasa dengan bahasa lain dalam satu ikatan kata. Ujaran yang tampak mengandung tipe intra-lexical tampak pada data di bawah ini.

$\begin{array}{ll}\text { Data } 3 \text { (Subyek 10) } \\ \text { Pembeli } & \text { Ada bawahan batik bu? } \\ \text { Penjual } & \begin{array}{l}\text { Banyak bu. Yang model apa? } \\ \text { Panjang atau pendek? }\end{array} \\ \text { Pembeli } & \begin{array}{l}\text { Yang panjang bu, model A } \\ \text { kalau ada. }\end{array} \\ \text { Penjual } & \text { Tak ambilkan dulu. } \\ \text { Pembeli } & \text { Kainnya yang bagus bu. } \\ \text { Penjual } & \text { Nah ini barangnya, kainne } \\ & \text { juga bagus. }\end{array}$

Data $3 \mathrm{di}$ atas berupa percakapan antara penjual dan pembeli yang bukan berasal dari Kota Pekalongan, sehingga bahasa yang digunakan sebagai pengantar percakapan adalah Bahasa Indonesia. Oleh karena itu, pelaku yang terlibat dalam percakapan tersebut menggunakan Bahasa Indonesia untuk menyampaikan tujuan pembicaraan. Akan tetapi, berdasarkan penggalan percakapan di atas, khususnya pada ujaran yang disampaikan oleh penjual pada baris terakhir "Nah ini barangnya, kainne juga bagus". Kata "kainne" pada ujaran tersebut merupakan ikatan kata yang berupa gabungan Bahasa Indonesia "kain" dan Bahasa Jawa "ne". Percampuran kata tersebut dikenal dengan istilah campur kode tipe intra-lexical.

Selain kata "kainne", beberapa kata pada percakapan antara penjual dan pembeli di Pasar Grosir Setono Pekalongan teridentifikasi ke dalam campur kode tipe intra-lexical. Kata-kata tersebut adalah "bajue", "batikane", "warnane", "panjange", "merahe"

\section{SIMPULAN DAN SARAN \\ 5.1. Simpulan}

Sejalan dengan pelaksanaan penelitian di atas dengan tujuan untuk mendeskripsikan tipe campur kode yang digunakan antar para penjual dan pembeli di Pasar Grosir Setono Pekalongan, maka dapat dikemukakan simpulan sebagai berikut: tipe campur kode pada percakapan antar para penjual dan pembeli di Pasar Grosir Setono Pekalongan adalah tipe inter-sentential dan tipe intra-lexical. Keduanya muncul pada ujaran bentuk dari Bahasa Jawa ke Bahasa Indonesia dan dari Bahasa Indonesia ke Bahasa Jawa.

\subsection{Saran}

Berdasarkan simpulan di atas, maka perlu adanya pelatihan penggunaan Bahasa Indonesia secara baik dan benar dalam bidang pemasaran. Hal ini dimaksudkan supaya para penjual bisa meningkatkan kemampuan kebahasaan mereka dan meningkatkan rasa percaya diri dalam menggunakan Bahasa Indonesia sebagai bahasa persatuan. Dengan penguasaan Bahasa Indonesia yang cukup, para penjual mampu meminimalisir terjadinya campur kode, yaitu penyisipan bahasa lain pada sebuah percakapan.

\section{REFERENSI}

Chaer, A. (1994). Linguistik Umum. Rineka Cipta.

Chaer, Abdul dan Agustina, L. (2010). Sosiolinguistik: Perkenalan Awal (Edisi Revisi). Rineka Cipta.

Effendy, O. U. (2002). Ilmu Komunikasi dan Praktek. PT Remaja Rosdakarya.

Hoffman, C. (1991). Introduction to Bilingualism. Longman. 
Kridalaksana, H. (2001). Kamus Linguistik. PT Gramedia Pustaka Utama.

Moleong, L. J. (2010). Metodologi Penelitian Kualitatif. Rosdakarya.

Rahmadani, Putri Markinda, W. T. dan K. (2015). Alih dan Campur Kode dalam Novel Sepatu Dahlan dan Implikasinya. Jurnal Kata (Bahasa, Sastra dan Pembelajarannya, 1-16.

Rohmadi, Muhammad, dkk. (2006). Sosiolinguistik, Kajian Teori dan Analisis. Pustaka Pelajar.

Sumarsono. (2011). Sosiolinguistik. Pustaka.

Wardhaugh, R. (2006). An Introduction to Sociolinguistics. Wiley-Blackwell. 